\title{
ПЕРЕКЛАДОЗНАВСТВО
}

УДК 811.81.161.2.

О. С. Бойван, О. В. Ковтун

\section{ОСОБЛИВОСТІ ПЕРЕКЛАДУ ТЕКСТІВ МІЛІТАРИСТИЧНОГО СПРЯМУВАННЯ НА ОСНОВІ КОМПЛЕМЕНТАРНОЇ ЄДНОСТІ МОВНИХ ЯВИЩ КОМПРЕСІЇ І ДЕКОМПРЕСІЇ}

Запропонована наукова розвідка окреслює загальнотеоретичні тендениії та основні характеристики вищезгаданої проблематики. Опрацьовані наукові джерела, що висвітлюють особливості мовних феноменів розширення та конденсування текстової інформації, засвідчують актуальність роботи, оскільки проблема мовних феноменів компресії $і$ декомпресії $є$ не повністю дослідженою, а особливо в процесі перекладу текстів мілітаристичного спрямування. Мета наукової розвідки - дослідити, теоретично проаналізувати, схарактеризувати та визначити специфіку застосування компресіі $i$ декомпресії в перекладі з англійської мови українською з опертям на приклади з текстів мілітаристичного спрямування. Досягнення мети стає можливим за умови розв'язання таких завдань: проаналізувати теоретичний матеріал, що висвітлює проблематику мовних феноменів компресії $і$ декомпресії; уточнити визначення мовних явищ, компресії $і$ декомпресії з урахуванням теоретичних аспектів досліджуваної проблематики.

Ключові слова: мовний феномен, компресія, декомпресія, розширення, конденсування, мілітаристичне спрямування, теоретичний аспект, уточнення, переклад.

Boivan O., Kovtun O. Translational Features of the Militaristic Texts on Basis of the Complementary Unity of the Language Phenomena of Compression and Decompression. The proposed scientific research "Translation Features of the Militaristic Texts on Basis of the Complementary Unity of the Language Phenomena of Compression and Decompression» outlines the general theoretical peculiarities and main characteristics of the mentioned above issues. Scientific sources covering the qualities of the linguistic phenomena of expansion and condensation of textual information have also been studied. The relevance of the work is determined by the fact that the topic of linguistic phenomena of compression and decompression is not fully explored, especially in the translation of militaristic texts.

The aim of the work is to investigate, analyze, characterize and determine the specifics of the use of compression and decompression in the translation from English into Ukrainian, based on the examples from militaristic texts. Achieving the goal 
becomes possible if the following tasks are solved: to analyze the theoretical material that covers the problems of linguistic phenomena of compression and decompression; to clarify the definition of linguistic phenomena of compression and decompression, based on the theoretical aspects of the studied issues.

It was clarified, compression is a natural, speech component that condenses information in order to save the content of texts functionally in the process of translation, in our case, the militaristic direction. That is, the use of a minimum of language tools to convey maximum content. And decompression is a natural, speech component that serves as a text-forming factor in the expansion and detailing of information through the introduction of additional words and sentences in the translation process.

Key words: language phenomenon, compression, decompression, expansion, condensation, militaristic orientation, theoretical aspect, clarification, translation.

\section{Вступ}

Так склалося історично, що процес розвитку людства не був можливим без постійної взаємодії і контактів представників різноманітних етносів. Відомо, що культура, традиція, мова розвиваються, власне, своїми особливими векторами залежно від територіальності, розуміння навколишнього буття, сприйняття внутрішніх особливостей побудови взаємостосунків тощо. Для досягнення повного розуміння в зовнішній взаємодії саме переклад слугує допоміжним складником і має широкий застосунок та вагому роль у процесі перемовин, договорів тощо.

Переклад $€$ поняттям історичним, і в різні епохи представники людства вкладали в нього свій зміст, притаманний особливостям тієї чи тієї мови. Переклад існує не тільки для засвоєння й розуміння чужого, але також для розвитку власної мови й культури (Камінський, 2007).

Працювати, ураховуючи особливості в перекладі іншомовних текстів, науковці достеменно почали лише на початку XX ст. Сьогодні у світі відбуваються численні міжнародні конференції, ділові зустрічі, брифінги, перемовини, пов'язані з військовою тенденцією. Проводять широкі міжнародні кампанії, спільні програми досліджень, підвищився обсяг міжнародної торгівлі, дипломатичної діяльності, міжнародного листування. Це все вимагає від перекладача швидкої адаптації до умов ситуації та гнучкості у виборі правильних тенденцій перекладу, тобто необхідно десь скоротити подану інформацію, 
пришвидшивши процес, а десь і розширити, звертаючи увагу на належні пояснення певних мовних особливостей, що забирає більше часу.

Перші поняття процесів компресії та декомпресії були згадані як частина такого феномену, як мовна економія і мовне розширення. Ідея про існування подібних законів у мові підтверджена дослідженнями зв'язків між мовою і мисленням. Людське сприйняття має такі характеристики, що будь-яка думка чітко не прив'язана до одного мовного вислову, а існує для вираження багатогранних думок та визначення мінімальної мовної форми, щоб «оживити» або висловити думку загалом (Шевченко, 2013: 65).

Феномени мовної економії та мовного розширення в мові й мовленні, можливо, і не є визначальними принципами мовного прогресу, але відіграють неабияку роль у взаємодії між представниками того чи того народу. Можна стверджувати, що питання компресії та декомпресії $€$ не надто дослідженою темою в лінгвістиці, однак вітчизняні й зарубіжні науковці плідно ії розробляли. Ці питання вивчали I. В. Арнольд (2012), Б. П. Дюндик(2003), С. В. Єрьомінко (2017), М. Н. Мілєєва (2018), Л. Л. Нелюбіна (2016), І. В. Полуян (2018), О. В. Тихомирова (2018), А. Д. Швейцер (1973). Малодосліджений статус вище згаданих мовних явищ не відміняє їх актуальності, оскільки вони наявні на всіх рівнях мови (фонетичному, морфологічному, лексичному, синтаксичному), а також відіграють важливу роль у процесі перекладу текстів з безеквівалентною лексикою.

Зокрема, було помічено, що проблематика мовної економії є більш досліджуваним науковим полем. Уважаємо, що це пов'язане з тим, що англійська $є$ аналітичною мовою, а українська синтетичною, тому мовний феномен компресії використовують здебільшого під час перекладу з української англійською, а декомпресію навпаки. Погоджуємося з визначенням, що конденсування і розширення тексту явища взаємообернені та взаємозалежні й відповідно до напрямку перекладу (з англійської чи з української) одне й те саме слово або словосполучення може виступати як декомпресованою, так і компресованою одиницею (Камінський, 2007: 61).

Мовне явище компресії частково показане в наукових роботах В. О. Богородицького (2013), Р. О. Будагова (1972), Л. Н. Мурзіна (1979), Г. Пауля (1960), С. Н. Ординської (2006) та ін. Та попри 
тривалу традицію дослідження вищезгаданої проблематики однозначного тлумачення ролі принципу економії в мовному розвитку досі немає. Тому актуальним аспектом виступає дослідження його виявів на синхронному етапі функціонування окремих мов, зокрема української, що є передумовою з'ясування значення принципу економії як загального лінгвістичного поняття (Макарець, 2013: 163).

Слід зазначити, що у військових текстах є величезна кількість спеціальної лексики й постійно спостерігається використання військової термінології. Також наявні стійкі визначення, притаманні для військової сфери, наприклад, команди, що є особливим видом стійких фразеологізмів, перетворилися на взаємний код і мають майже знаковий характер. Їх не можна вільно перекладати українською мовою, а слід запам'ятовувати, інакше неправильно перекладена команда або наказ втратять свою чіткість; у них немає варіантів, оскільки це сталі одиниці, усередині яких нічого не можна змінювати (Волік, 2012: 39).

До військових текстів відносять такі: військово-художні матеріали, військово-публіцистичні, військово-політичні, військово-наукові й військово-технічні та акти військового управління, тобто різні військові документи. Військово-публіцистичні, військово-політичні $€$ військовими лише за тематикою та цілеспрямованістю, однак вони мають ті самі риси, що й усі суспільно-політичні та публіцистичні твори (Зайцева, 2013: 97).

Актуальність роботи визначається тим, що тема мовних феноменів компресії і декомпресії $є$ не повністю дослідженою, а особливо в процесі перекладу текстів мілітаристичного спрямування.

Мета наукової розвідки - дослідити, теоретично проаналізувати, схарактеризувати та визначити специфіку застосування компресії і декомпресії в процесі перекладу з англійської мови українською на прикладах з текстів мілітаристичного спрямування. Досягнення мети стає можливим за умови розв'язання таких завдань: 1) проаналізувати теоретичний матеріал, що висвітлює проблематику мовних феноменів компресії і декомпресії; 2) уточнити визначення мовних феноменів компресії і декомпресії з опертям на теоретичні аспекти досліджуваної проблематики; 3) визначити різновиди мовної компресії і декомпресії за рівнями мови, що трапляються в текстах мілітаристичного спрямування. 


\section{Методи дослідження}

Використані методи відповідають поставленій меті та завданням. Методологія дослідження грунтується на принципі системного лінгвістичного аналізу тексту й окремих його складників - особливостей використання мовних феноменів компресії й декомпресії в процесі перекладу твору мілітаристичного спрямування. До загальних принципів нашої наукової розвідки можна віднести історизм, об’єктивність, конкретність і плюралізм. У процесі підготовки роботи було використано лінгвістичні, літературознавчі, культурологічні, структурнофункціональні, системні, соціально-психологічні й історичні методи, а також методи аналізу, синтезу, гіпотези та емпірично-науковий метод — аналіз тексту (контент-аналіз).

\section{Виклад основного матеріалу}

На сучасному етапі розвитку суспільства значні обсяги інформації потребують усе більш стислих засобів їх передавання, у чому й полягає актуальність вивчення причин появи мовної компресії. Серед об'єктивних причин виникнення мовної компресії можна виділити дві підгрупи:

- матеріальні (економія матеріальних і розумових ресурсів);

- технічні (економія місця на папері).

Однією з найважливіших причин лінгвістичної компресії $є$ необхідність економити матеріальні засоби, а саме грошові витрати, ресурси паперу тощо (Шевченко, 2013: 67).

Важливою суб'єктивною причиною компресії тексту є й прагнення автора створити певний стилістичний ефект. Прикладами текстів, що були створені під іï впливом, можуть бути анекдоти й афоризми. Анекдот як жанр гумористичного спілкування будується на абсурді, при цьому певна ситуація має вигляд абсолютно безглуздої, але не зачіпає змістовних життєвих орієнтирів адресата. Абсурдність моделюється як опозитивна ознака, має потрійну проекцію (Шевченко, 2013: 67). Можемо запевнити, що існує чимало анекдотів, дотепних жартів на військову тематику. I, наприклад, під час «smalltalks» вони $€$ доречними, щоб налаштуватись на позитивну атмосферу перед діловою розмовою або перемовинами двох сторін.

Наприклад, «The Sergeant-Major growled at the young soldier: "I didn't see you at camouflage training this morning". Young soldier 
answers: "Thank you very much, sir"». (Сержант-майор гаркнув до молодого солдата: «Я не бачив тебе на навчаннях з камубляжу вранці» Солдат відповів: «Дякую за комплімент, сер»). Або ж: «A senior chief, when addressing his 25 sailors, says, "I have an easy job for the laziest man here. Put your hand up if you are indeed the laziest". Almost immediately, 24 men raise their hands. The senior chief asks the other man, "Why didn't you raise your hand?" The sailor replies, "Because it was too much trouble, senior chief”». (Старшина звертається до своїх 25 моряків: "Найлінивіший чоловік тут отримає найлегшу роботу, підніми руку - той, хто з вас найлінивіший». Майже відразу 24 людини підняли руку. Стариина питає того, хто не підняв руку: «Чому ти не підняв руку?» Моряк відповідає: Не хочу себе обтяжувати, товаришу стариина»).

Дослідниця О. В. Тріщук вважає, що одним з найефективніших і найдієвіших способів конденсування інформації з одночасним зменшенням словесного обсягу в наукових текстах $є$ використання термінів і термінологічних сполук, що порівняно зі звичайними словами передають більше інформації та забезпечують однозначне й глибоке усвідомлення їі змісту читачем (Тріщук, 2016: 91).

Уживання таких термінів дає можливість коротко подавати розгорнені визначення і характеристики. Наприклад, artillerybattalion перекладаються одним терміном - 'дивізіон'; attackaircraft - 'штурмовик' Вони допомагають стисло виражати суть понять, фактів, процесів і т. ін.

Також поширеним засобом ущільнення в наукових текстах можна вважати різні види графічних, умовних скорочень слів, що поширені лише на письмі й розшифровуються під час прочитання вголос. Наприклад, atkacft читається як attackaircraft і перекладається як штурмовик; ADP читається як automaticdataprocessing, перекладається як автоматична обробка даних. Такі буквені скорочення, виявлені в словниковій дефініції, можуть бути розподілені на дві великі групи:

- традиційні буквені скорочення, що можуть функціонувати в усіх жанрах і стилях мови: A. D. (Anno Domini), B. C. (before Christ), etc. (et cetera), S (South), SW (South West).

- специфічні буквені скорочення, типові для словників: cf. (confer = compare), S (spoken), W (written), pp (pastpartici pleorpages) (Шевченко, 2013: 68). 
Дослідники розуміють компресію по-різному: одні вважають, що вона досягається шляхом уникнення надлишкових елементів висловлення, що будуть зрозумілі з контексту; на думку інших, компресія $€$ закономірним перетворенням вторинного порядку, яке застосовують для надання складним конструкціям більш простого вигляду. Ми погоджуємося $з$ думками науковців, які наголошували на тому, що мовне конденсування виникає через розгалужену систему більш компактних граматичних структур в англійській мові, тобто компресія $€$ методом, за допомогою якого надають складним й інколи заплутаним конструкціям зрозумілого вигляду. Слід уточнити, компресія - це закономірний, мовно-мовленнєвий складник, щзо конденсує інформацію з метою функціональної економї змісту текстів у процесі перекладу, зокрема й мілітаристичного спрямування, тобто використання мінімуму мовних засобів для передачі максимального змісту.

Термін «декомпресія» має латинське походження і складається з префікса de-, що виражає позбавлення, відсутність, та основи compressio - стискання, лаконічність. Є багато чинників, при яких використовують феномен декомпресії, одним з них, безумовно, $€$ культурний, адже, розкриваючи своєрідність мови, ми постійно помічаємо, що одні й ті самі явища неоднаково проявляються в різних мовних середовищах.

У теоретичних працях декомпресію визначають як лінійне або вертикальне розширення мовної одиниці, що виникає внаслідок необхідності заповнення лакун у генетично неспоріднених мовах (Рєзанова, 2015). У контексті нашого дослідження це українська й англійська мови, що $є$ неспорідненими, а отже, вимагають використання декомпресії під час перекладу.

Декомпресія - явище протилежне явищу компресії, а тому основною ознакою цього феномену $є$ умисне введення надлишковості в текст з метою пояснення, уточнення й використання таких перекладацьких трансформацій і прийомів, що дають «можливість відобразити увесь спектр змісту без еквівалентної мовної одиниці» (Тріщук, 2016: 92).

Основними прийомами декомпресії є додавання й розширений опис, коли до тексту доповнюють слова, що пояснюють або уточнюють реалії та безеквівалентну лексику.

Наприклад, activedefenses, що переклали як 'засоби активної оборони' та airtransportable, яке перекладають як 'придатний для 
транспортування повітрям’. Його використовують для збереження логіки викладу думок, що забезпечує зв'язність тексту.

Також декомпресію застосовують для конкретизації висловлювань. Удалим прикладом $є$ переклад слів 2-milerun, що переклали як 'крос на дистанцію у 2 милі', та adjudication, яке переклали як 'вирішення в судовому порядку'

Ю. І. Камінський зауважує, що англійська мова є аналітичною за своєю натурою і тому переклад з неї українською практично завжди буде супроводжуватись застосуванням декомпресії. Він зробив висновок, що декомпресію під час перекладу з англійської мови українською використовують частіше, ніж компресію. Однак учений також додав, що перспективою дослідження є аналіз суспільно-політичних текстів (з урахуванням контексту) з метою підтвердження цієї гіпотези (Камінський, 2007: 62). Ми погоджуємося із цим твердженням.

Тобто декомпресія є явищем взаємопротилежним явищу компреciї: якщо під час використання компресії ми стискаємо інформацію, то в процесі декомпресіі, навпаки, розширюємо іiі. Це відбувається через відсутність еквівалентів у мові оригіналу й мові перекладу. Вона $\epsilon$ умисним уведенням надлишковості в тексті з метою пояснення, уточнення і використання перекладацьких трансформацій та прийомів, що дають можливість відобразити зміст безеквівалентної мовної одиниці. Різні науковці надають своє визначення декомпресії. Зокрема, декомпресія - це феномен розширення первинного тексту, при цьому його комунікативна цінність зростає. Уточнюємо, щзо декомпресія - ие закономірний, мовно-мовленнєвий складник, що слугує текстотвірним чинником розширення й деталізачії інформачії за допомогою введення додаткових слів та речень у процесі перекладу.

Як уже зазначалося, на сучасному полі лінгвонаук немає цілісного, послідовного й системного розуміння понять компресії та декомпресії. Потреба в науковій розвідці цієї проблематики зумовлена не лише вузькоспеціалізованим лінгвістичним підходом, а й сучасним станом суспільства, яке вчиться існувати й активно діяти в інформаційно-технологічну епоху, особливо в комп'ютерній сфері, що безпосередньо має вплив на мілітаристичний напрямок і його розробки. Перед науковцями різних галузей гостро постає питання повноцінного інформаційного обміну й водночас економної або розширеної передачі мовних сигналів. Лаконічність і правильність думки під час 
перекладу є невід'ємною вимогою професійного перекладу, але залишається необхідним факт роз'яснення носію іншої культури певних незрозумілих понять чи явищ. Проблема точної інтерпретації інформації у військової галузі, вираженої в одній мові засобами іншої, $є$ актуальною в перекладознавстві й лінгвістиці, а також в інших галузях науки, що пов'язані з мілітаристичною сферою.

Тому в процесі нашого дослідження виникла нагальна потреба створення схематичної форми мовних феноменів компресії та декомпресії. За основу ми взяли наукові розвідки С.В. Єрьоменка, Ю.І. Камінського, В.І. Карабана, Ю.В. Керпатенка, щоб у подальших дослідженнях опиратися саме на зафіксовані схематичні дані (див. рис. 1) для практичної характеристики стиснення або розширення текстової інформації.

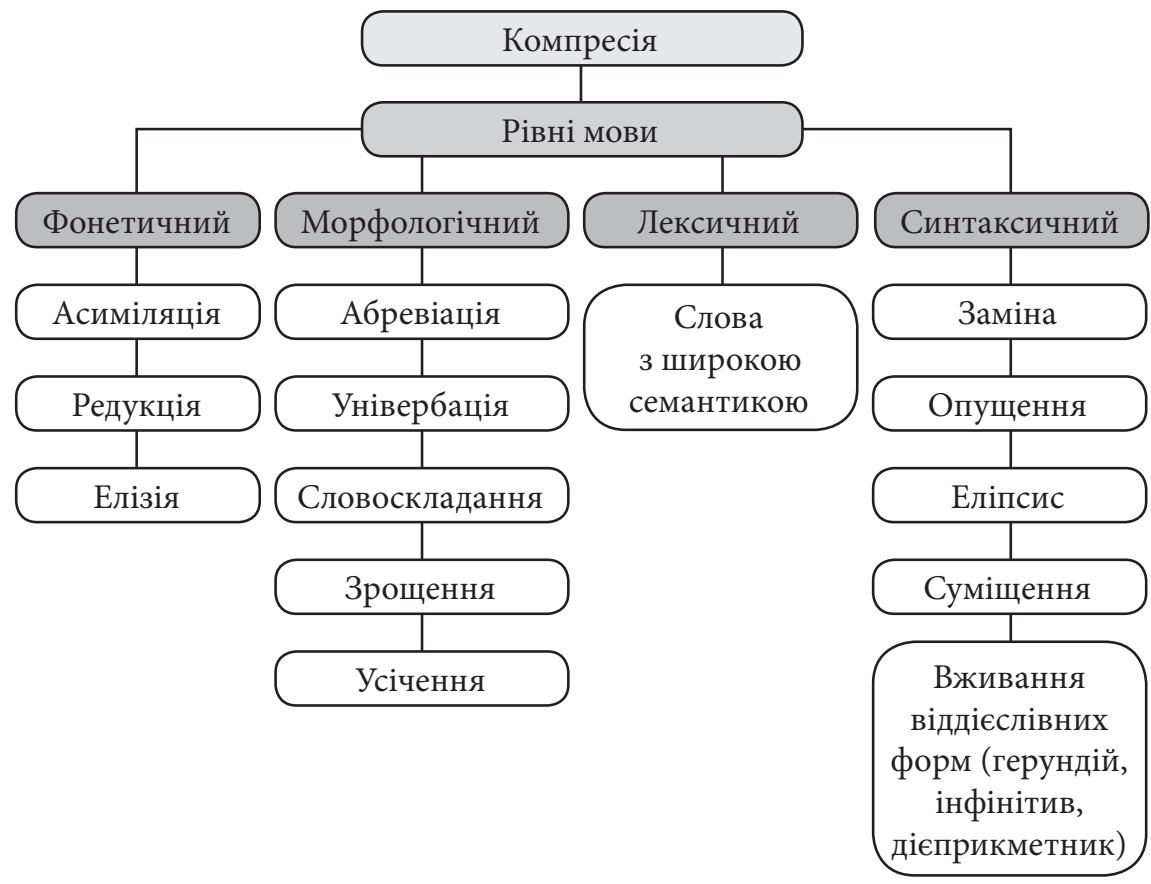

Далі розглянемо схожу схему з декомпресією. Вона є дещо меншою, і в ній немає фонетичного рівня, оскільки мовленнєва декомпресія, хоча й не існує відокремлено, меншою мірою піддається підпорядкуванню нормам мовної системи. 


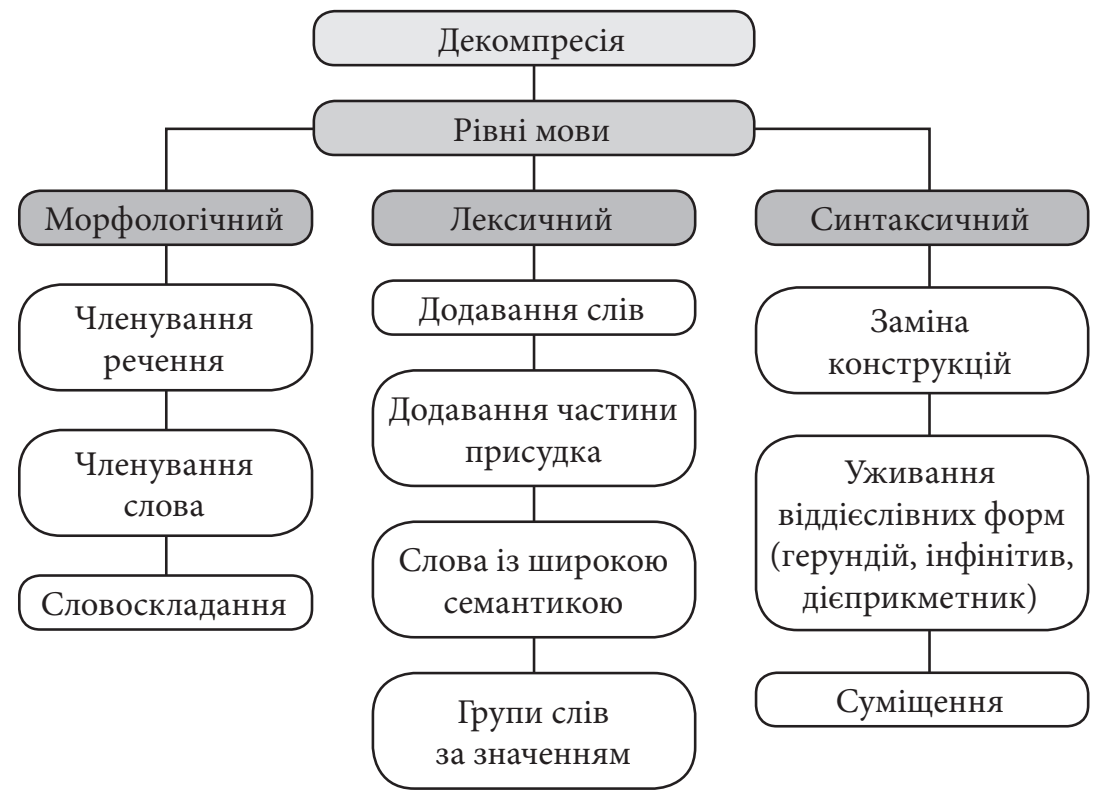

\section{Висновки}

Отже, більшість військових текстів, з якими працюють перекладачі, функціонують у межах чотирьох стилів: розмовного, офіційноділового, інформаційно-публіцистичного, науково-технічного. Через особливості військових текстів під час перекладу вони потребують використання мовних феноменів компресії і декомпресії, які визначаються як закономірні складники мови, що спричинені прагненням перекладачів полегшити, оптимізувати й пристосувати власні бачення та зусилля в процесі мовлення для повноцінної передачі інформації.

Однією із цих особливостей $є$ широка термінологія, до якої не завжди можливо знайти відповідники, і тому використовуються вищезгадані феномени. Вимоги до військового перекладача винятково високі, він вимагає спеціальної підготовки, навичок і вмінь. Цей переклад із самого початку його виокремлення в межах перекладознавства було досліджено переважно в прикладному й лінгводидактичному аспектах. Теорія військового перекладу займається узагальненням знань про переклад цього типу. Ми погоджуємось, що сьогодні вона немислима без глибокого знання теорії та осмислення всієї складності процесу перекладу. 
Отже, процеси мовної компресії і декомпресії $€$ важливими складниками перекладу, хоча вони й досі не досліджені ретельно, але це не заперечує їхньої актуальності, оскільки, такі феномени можна знайти на всіх рівнях мови. Наявність компресії дає змогу робити тексти лаконічними й інформаційно насиченими, а наявність декомпресії уможливлює розширення тексту для того, щоб досягти комунікативної еквівалентності. Убачаємо перспективною подальшу роботу з більш чітким акцентом на практичний аспект аналізу й характеристики мовних явищ компресії та декомпресії на основі обраного художнього твору мілітаристичного спрямування.

\section{ЛІТЕРАТУРА}

1. Волік, Л. А. (2012). Переклад англійської військової термінології українською мовою. Перекладацькі інновації: матеріали II Всеукраїнської студентської науково-практичної конференції (с. 38-39). Суми : СумДУ. 2. Зайцева, М. О. (2013). Особливості перекладу термінів у текстах на військову тематику. Науковий часопис Національного педагогічного університету імені М. П. Драгоманова. Серія 9: Сучасні тенденції розвитку мов, 10, 96-102. Київ: НПУ ім. М.П. Драгоманова. 3. Камінський, Ю. І. (2007). Декомпресія в суспільно-політичному дискурсі (лексикографічний аспект). Науковий часопис Начіонального педагогічного університету імені М. П. Драгоманова. Серія 9: Сучасні тенденції розвитку мов, 2, 60-63. Київ: НПУ ім. М.П. Драгоманова. 4. Ктитарова, Н. К., \& Воронова, 3. Ю. (2013). Навчальний посібник з дисиипліни «Теорія перекладу» (Вступ до перекладознавства. Загальна теорія перекладу. Лексико-граматичні проблеми перекладу) для студентів спеціальності 7.030507 «Переклад». Дніпродзержинськ. 5. Макарець, Ю. С. (2013). До питання про принцип економії в мові та мовленні. Науковий часопис Національного педагогічного університету імені М. П. Драгоманова. Серія 10: Проблеми граматики і лексикології української мови, 10, 161-168. 6. Резанова, М.(2015). Додавання та опис як основні прийоми методу декомпресії. Узято з http://eprints.zu.edu.ua/19042/. 7. Тріщук, О. В. (2016). Основні способи компресії науково-інформаційного тексту. Технологія $і$ техніка друкарства, 3 (53), 88-97. 8. Шевцова, О. В. (2012). Лексичні трансформації при еквівалентному перекладі конвенцій з англійської та французької мов українською. Наукові записки Національного університету «Острозька академія». Серія: Філологічна, 30, 175-178. 9. Шевченко, М. Ю. (2013). Причини виникнення мовної компресії в англійській мові. Лінгвістика, 2, 64-72.

\section{REFERENCES}

1. Volik, L. A. (2012). Pereklad anhliiskoi viiskovoi terminolohii ukrainskoi umovoiu [Translation of English military terminology into Ukrainian]. Perekladatski innovatsii: materialy II Vseukrainskoi studentskoi naukovo-praktychnoi konferentsii - Translation innovations: materials of the II All-Ukrainian students cientific-practical conference (pp. 3839). Sumy : SumDU [in Ukrainian]. 2. Zaitseva, M. O. (2013). Osoblyvosti perekladu terminiv $\mathrm{u}$ tekstakh na viiskovu tematyku [Features of translation of terms in texts on 
military subjects]. Naukovyi chasopys Natsionalnoho pedahohichnoho universytetu imeni M. P. Drahomanova. Seriia 9: Suchasni tendentsii rozvytku mov - Scientific journal of the M. P. Drahomanov National Pedagogical University. Series 9: Current trends in language development, 10, 96-102. Kyiv: NPU im. M. P. Drahomanova [in Ukrainian]. 3. Kaminskyi, Yu. I. (2007). Dekompresiia v suspilno-politychnomu dyskursi (leksykohrafichnyi aspekt). [Decompression in socio-political discourse (lexicographic aspect)] Naukovyi chasopys Natsionalno hopedahohichnoho universytetu imeni M. P. Drahomanova. Seriia 9: Suchasni tendentsii rozvytku mov - Scientific journal of the M. P. Drahomanov National Pedagogical University. Series 9: Current trends in language development, 2, 60-63. Kyiv: NPU im. M. P. Drahomanova [in Ukrainian]. 4. Ktytarova, N. K., \& Voronova, Z. Iu. (2013). Navchalnyi posibnyk $z$ dystsypliny «Teoriia perekladu» (Vstup do perekladoznavstva. Zahalna teoriia perekladu. Leksyko-hramatychni problemy perekladu) dlia studentiv spetsialnosti 7.030507 «Pereklad» [Textbook on the subject "Theory of Translation" (Introduction to Translation Studies. General Theory of Translation. Lexical and grammatical problems of translation) for students majoring in 7.030507 "Translation"]. Dniprodzerzhynsk [in Ukrainian]. 5. Makarets, Yu. S. (2013). Do pytannia pro pryntsyp ekonomii v movi ta movlenni [On the question of the principle of economy in language and speech]. Naukovyi chasopys Natsionalnoho pedahohichnoho universytetu imeni M. P. Drahomanova. Seriia 10: Problemy hramatyky i leksykolohii ukrainskoi movy - Scientific journal of the M. P. Drahomanov National Pedagogical University.Series 10: Problems of grammar and lexicology of the Ukrainian language, 10, 161-168 [in Ukrainian]. 6. Riezanova, M. (2015). Dodavannia ta opys yak osnovni pryiomy metodu dekompresii [Addition and description as the main methods of decompression]. Retrieved from http://eprints.zu.edu.ua/19042/ [in Ukrainian]. 7. Trishchuk, O. V. (2016). Osnovni sposoby kompresii naukovo-informatsiinoho tekstu [The main methods of compression of scientific information text]. Tekhnolohiia i tekhnika drukarstva - Printing technology and technique, 3(53), 88-97 [in Ukrainian]. 8. Shevtsova, O. V. (2012). Leksychni transformatsii pry ekvivalentnomu perekladi konventsii z anhliiskoi ta frantsuzkoi mov ukrainskoiu [Lexical transformations with equivalent translation of conventions from English and French into Ukrainian]. Naukovi zapysky Natsionalnoho universytetu «Ostrozka akademiia». Seriia: Filolohichna - Scientific notes of the National University» Ostroh Academy». Series: Philological, 30, 175-178 [inUkrainian]. 9. Shevchenko, M. Yu. (2013). Prychyny vynyknennia movnoi kompresii v anhliiskii movi [Causes of speech compression in English]. Linhvistyka - Linguistics, 2, 64-72 [in Ukrainian].

Бойван Олеся Степанівна - кандидат педагогічних наук, доцент кафедри теоpiї і практики перекладу факультету іноземних мов, Донецький національний університет імені Василя Стуса; вул. Академіка Янгеля, 4, Вінниця, 21007, Україна.

$$
\begin{aligned}
& \text { Tel.: +380972244554 } \\
& \text { E-mail: olesiaboivan@gmail.com } \\
& \text { http://orcid.org/ 0000-0002-3512-0315 }
\end{aligned}
$$

Boivan Olesia Stepanivna - Ph.D. in Pedagogy, Associate Professor at the Department of the Theory and Practice of Translation, Faculty of Foreign Languages Vasyl' Stus Donetsk National University; Akademika Yanhelia Str., 4, Vinnytsia, 21007, Ukraine. 
Ковтун Оксана Володимирівна - кандидат філологічних наук, доцент кафедри теорії і практики перекладу факультету іноземних мов, Донецький національний університет імені Василя Стуса; вул. Академіка Янгеля, 4, Вінниця, 21007, Україна.

Tel.: +380979611640

E-mail: o.kovtun@donnu.edu.ua

https://orcid.org/0000-0002-9139-8987

Kovtun Oksana Volodymyrivna - Ph.D. in Philology, Associate Professor at the Department of the Theory and Practice of Translation, Faculty of Foreign Languages, Vasyl' Stus Donetsk National University; Akademika Yanhelia Str., 4, Vinnytsia, 21007, Ukraine.

Надійшла до редакції 12 вересня 2020 року

\section{CITATION}

ДСТУ 8302:2015: Бойван О. С., Ковтун О. В. Особливості перекладу текстів мілітаристичного спрямування на основі комплементарної єдності мовних явищ компресії і декомпресії. Лінгвістичні дослідження: зб. наук. пр. Харк. нац. пед. ун-ту імені Г. С. Сковороди. Харків, 2020. Вип. 53. С. 63-75. DOI: https://doi.org/10.34142/ 23127546.2020.53.06

APA: Бойван, О. С., \& Ковтун, О. В. (2020). Особливості перекладу текстів мілітаристичного спрямування на основі комплементарної єдності мовних явищ компресії і декомпресії. Лінгвістичні дослідження, 53, 63-75. DOI: https://doi.org/10.34142/ 23127546.2020.53.06 